\title{
Mortality in Patients with Biopsy-proven Giant Cell Arteritis: A South Australian Population-based Study
}

\author{
JEM NINAN, ANH-MINH NGUYEN, ANTONIA COLE, MAUREEN RISCHMUELLER, THOMAS DODD, \\ PETER ROBERTS-THOMSON, and CATHERINE L. HILL
}

\begin{abstract}
Objective. To compare mortality rates and cause of death in patients with biopsy-proven giant cell arteritis (GCA) with those in the general population.

Methods. Patients with biopsy-proven GCA were identified from pathology reports of temporal artery biopsies in South Australia, from January 1, 1992, to December 31, 2006. All patients with biopsy-proven GCA were linked to the South Australian Births, Death and Marriage Registry to identify deaths until December 31, 2006. Standardized mortality ratios and relative survival (ratio of observed survival in GCA group to expected survival of general South Australian population, matched by age, sex, and calendar time) were calculated. The cause of death recorded on the death certificate was also documented.

Results. There were 225 cases of biopsy-proven GCA (163 women and 62 men). The mean age at diagnosis of GCA was 78.2 years. The mean followup period was 66.2 months (SD $47.1 \mathrm{mo}$ ). During the followup period, there were 71 deaths in the GCA group (50 women, $21 \mathrm{men}$ ). The standardized mortality ratio was 0.99 (95\% CI $0.77-1.25)$. The relative survival for different followup periods demonstrates that patients with GCA experienced similar mortality to the general population (age-matched and sex-matched). Death from cardiovascular causes (45\%) was the most common, followed by infection $(17 \%)$ and cancer $(17 \%)$. Infection was a significantly more common cause of death in the first year (chi-squared, $\mathrm{p}=0.0002$ ).

Conclusion. Our population-based cohort study did not demonstrate any increased mortality risk for patients diagnosed with biopsy-proven GCA. The risk of death from infection early in the disease may be increased. (First Release Aug 15 2011; J Rheumatol 2011;38:2215-17; doi:10.3899/jrheum.101254)
\end{abstract}

Key Indexing Terms:

MORTALITY RATE

GIANT CELL ARTERITIS

BIOPSY-PROVEN

Giant cell arteritis (GCA) is a disease of the elderly that is associated with increased morbidity both from complications of vasculitis such as blindness, stroke, myocardial infarction, and aortic aneurysm and from complications of corticosteroid therapy including infection, osteoporosis, and impaired glycemic control. Previous studies of mortality associated with GCA have shown conflicting results, with some studies suggesting no effect on mortality ${ }^{1,2,3}$ and others that suggest increased mortality ${ }^{4,5}$. Many of these studies have been limit-

From the Rheumatology Unit, The Queen Elizabeth Hospital; the Health Statistics Unit, Department of Health; the Department of Tissue Pathology, SA Pathology; the Department of Allergy, Immunology and Arthritis, Flinders Medical Centre; and The Health Observatory, University of Adelaide, Woodville, Australia.

J. Ninan, MBBS, Rheumatology Unit, The Queen Elizabeth Hospital; A-M. Nguyen, BSc(Hons), Health Statistics Unit, Department of Health; A. Cole, FRACP, Rheumatology Unit, The Queen Elizabeth Hospital; M. Rischmueller, FRACP, Rheumatology Unit, The Queen Elizabeth Hospital; T. Dodd, FRCPA, Department of Tissue Pathology, SA Pathology; P. Roberts-Thomson, FRACP, Department of Allergy, Immunology and Arthritis, Flinders Medical Centre; C.L. Hill, FRACP, Associate Professor, Rheumatology Unit, The Queen Elizabeth Hospital, and The Health Observatory, University of Adelaide.

Address correspondence to Dr. C. Hill, Rheumatology Unit, The Queen

Elizabeth Hospital, 28 Woodville Road, Woodville 5011, Australia.

E-mail: Catherine.Hill@health.sa.gov.au

Accepted for publication May 25, 2011. ed by small sample size or inclusion of GCA cases not confirmed by biopsy. The aim of this study was to determine the mortality rate of patients with biopsy-proven GCA compared to the general population and to determine causes of death among these patients.

\section{MATERIALS AND METHODS}

Ascertainment of biopsy-proven GCA cases. All pathology reports of patients who underwent temporal artery biopsy were identified from pathology laboratories at the 3 major South Australian adult teaching hospitals (The Queen Elizabeth Hospital, the Royal Adelaide Hospital, and Flinders Medical Centre). These laboratories process about $85 \%$ of biopsy specimens from both public and private hospitals in South Australia.

Temporal artery biopsies were identified at The Queen Elizabeth Hospital and the Royal Adelaide Hospital in the period January 1, 1992, to December 31, 2006, and at Flinders Medical Centre from January 1, 1995, to December $31,2006$.

All pathology reports of temporal artery biopsies during this period were reviewed and patients with biopsy-proven GCA were identified. Patients were defined as having biopsy-proven GCA if this diagnosis was made by the reviewing pathologist on the diagnostic report ${ }^{6}$.

Ascertainment of death. Using Automatch software (MatchWare Technologies Inc., Tampa, FL, USA), all patients identified with biopsy-proven GCA were linked to the South Australian Registry of Births, Deaths and Marriages (BDM) to identify all deaths among these subjects prior to January 1,2007 . The BDM registry records all deaths that occur in South Australia (SA) and gathers data about all deaths in Australia. For those patients who died in SA, the primary cause of death as documented by the 
treating doctor on the death certificate was recorded. However, other diseases contributing to death may also be recorded by the treating doctor. No death certificate information is available for those people who died intestate.

Analysis. A historic cohort analysis was undertaken, using Stata 6.0 software (Stata Corp., College Station, TX, USA). Patients with biopsy-proven GCA were followed from their date of temporal artery biopsy until either their death or December 31, 2006, whichever came first. Each month of followup was classified by calendar year and by sex of patients and age at that time. To determine the risk of death in patients with biopsy-proven GCA after the diagnosis, the number of expected deaths in this cohort was calculated by applying mortality rates for SA, classified by calendar year, age, and sex, to these months of followup. The mortality risk in the general SA population was compared to the patients with biopsy-proven GCA.

Indirectly standardized mortality ratios (SMR) were obtained by dividing the numbers of deaths observed with the numbers expected, and deriving $95 \% \mathrm{CI}$ of these ratios from the Poisson distribution. The SMR uses the general SA population as the referent group; therefore, by definition this group will have a SMR of 1.0.

\section{RESULTS}

There were 225 cases of biopsy-proven GCA; of these, 163 $(72.4 \%)$ were women and $62(27.6 \%)$ were men. The majority of patients were white $(224 / 225,99.5 \%)$. The mean age at diagnosis of GCA was 78.2 years. The mean followup period was 66.2 months (SD $47.1 \mathrm{mo}$ ). During the followup period, there were 71 deaths in the GCA group (50 women, 21 men). The median time to death post-diagnosis was 49 months. The overall SMR was 0.99 (95\% CI 0.77-1.25). The SMR for women was 1.12 (95\% CI 0.83-1.48) and for men, $0.86(95 \%$ CI $0.53-1.32)$. The relative survival for different followup periods demonstrates that patients with GCA experienced similar mortality to the general population (age-matched and sex-matched; Table 1, Figure 1). Observed survival is described in Table 2. Death from cardiovascular causes (45\%) was the most common, followed by infection (17\%) and cancer (17\%; Table 3). Cardiovascular causes included myocardial infarction (11), cerebrovascular events (6), and mesenteric infarction (4). GCA was recorded on only 12 death certificates $(17 \%)$. The most frequent cause of death in the first year from GCA diagnosis was infection-related $(8 / 15,53 \%)$, including pneumonia (4) and pseudomonas septicemia (2). Infection was a significantly more common cause of death in the first year (chi-squared 14.03, p = 0.0002) than in later years, when cardiovascular causes were more common. There were no deaths due to cerebrovascular accident in the first year after diagnosis.

\section{DISCUSSION}

Our study showed similar mortality rates in patients with GCA to an age-matched and sex-matched control population. The strengths of our study are that it included only patients

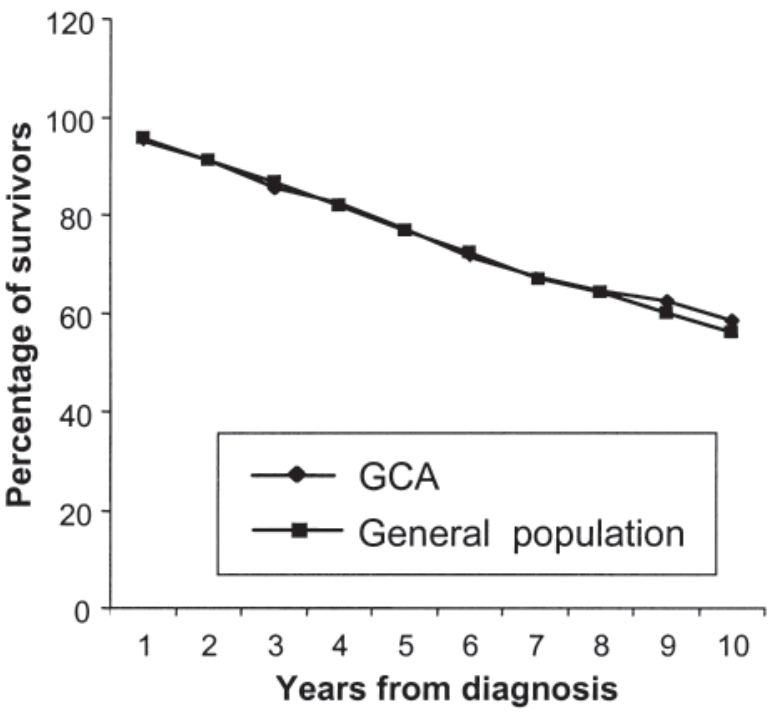

Figure 1. Survival rate of patients with giant cell arteritis compared with agematched general population.

with a confirmed diagnosis of GCA through biopsy and a large sample size (only a Swedish study by Nordborg and Bengtsson in 1989 with 284 patients being larger ${ }^{7}$ ). Another strength of our study is that death was ascertained from the state death registry and not from case note records alone, a practice that can lead to incomplete death ascertainment. Our study represents the first study of mortality in GCA outside Europe or North America. Previous studies have been from the United Kingdom, Europe, and the United States. We demonstrated no difference in survival from the general population at any time, a finding that contrasts with several studies that demonstrated increased mortality at 5 years, but no effect at $10-11$ years $^{4,8}$.

Studies that have demonstrated increased mortality of patients with GCA compared to the general population have generally been the studies with fewer patients (Bisgard ${ }^{9}, \mathrm{n}=34$; $_{\text {Garcia-Porrua }}{ }^{4}, \mathrm{n}$ $=54 ;$ Nesher $^{10}, \mathrm{n}=43$; Uddhammar ${ }^{11}, \mathrm{n}=136$ ). Studies that showed no increased mortality tended to involve more patients (Gonzalez-Gay $^{2}, \mathrm{n}=109$; $\mathrm{Gran}^{3}, \mathrm{n}=42$; Matteson $^{12}, \mathrm{n}=205$; Salvarani $^{13}, \mathrm{n}=173$; Nordborg and Bengtsson ${ }^{7}, \mathrm{n}=284$ ).

The earliest study comparing GCA mortality to the general population was performed in Olmsted County, Minnesota, $\mathrm{USA}^{14}$, in 1978 and revealed no increased risk. A subsequent study of the GCA cohort based at the Mayo Clinic also revealed no increased risk ${ }^{13}$. The only multinational study, by Matteson, et $a l^{12}$, included 205 patients with GCA from the United States, Canada, and Mexico, and also demonstrated no

Table 1. Relative survival ( \pm SE) of patients with biopsy-proven giant cell arteritis (GCA) in South Australia, compared to the general population, $1992-2006$ $(\mathrm{n}=225)$. All data are percentages.

\begin{tabular}{|c|c|c|c|c|c|c|c|c|c|c|}
\hline & & & & & & Year from $B$ & psy & & & \\
\hline & 1 & 2 & 3 & 4 & 5 & 6 & 7 & 8 & 9 & 10 \\
\hline GCA & $99.3 \pm 3.1$ & $99.8 \pm 4.4$ & $98.7 \pm 5.8$ & $100.5 \pm 6.8$ & $100.4 \pm 8.1$ & $98.7 \pm 9.6$ & $100.5 \pm 10.8$ & $100.3 \pm 12.4$ & $103.8 \pm 13.8$ & $104.2 \pm 15.8$ \\
\hline
\end{tabular}


Table 2. Observed survival of a giant cell arteritis (GCA) cohort (Kaplan-Meier estimates \pm SE), South Australia, 1992-2006. All data are percentages.

\begin{tabular}{|c|c|c|c|c|c|c|c|c|c|c|}
\hline & & & & & & Year from $\mathrm{I}$ & & & & \\
\hline & 1 & 2 & 3 & 4 & 5 & 6 & 7 & 8 & 9 & 10 \\
\hline GCA & $95.0 \pm 1.5$ & $91.0 \pm 2.0$ & $85.5 \pm 2.5$ & $82.4 \pm 2.8$ & $77.0 \pm 3.2$ & $71.4 \pm 3.5$ & $67.5 \pm 3.8$ & $64.4 \pm 4.0$ & $62.2 \pm 4.1$ & $58.4 \pm 4.4$ \\
\hline
\end{tabular}

Table 3. Cause of death in patients with biopsy-proven giant cell arteritis, 1992-2006.

\begin{tabular}{|c|c|c|c|c|c|}
\hline Cause of Death & Total, $\mathrm{n}=71(\%)$ & Men, $\mathrm{n}=21$ & Women, $\mathrm{n}=50$ & $\begin{array}{l}\text { Mean Age at } \\
\text { Death, yrs }\end{array}$ & $\begin{array}{l}\text { Median Duration from } \\
\text { Diagnosis, months (range) }\end{array}$ \\
\hline Cardiovascular & $32(45)$ & 10 & 22 & 86.4 & $60(6-173)$ \\
\hline Cancer & $12(17)$ & 3 & 9 & 77.4 & $43.5(15-129)$ \\
\hline Respiratory & $5(7)$ & 2 & 3 & 79.6 & $13(3-170)$ \\
\hline GIT & $5(7)$ & 2 & 3 & 86.2 & $47(31-106)$ \\
\hline
\end{tabular}

* These included renal failure, motor neuron disease, and death from unknown cause. GIT: gastrointestinal tract.

increased risk (SMR 1.03). However, studies from Denmark, Spain, Israel, and Utah, USA, have shown variably increased

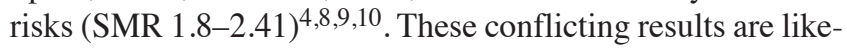
ly related to differences in ascertainment of GCA, as well as variability of duration and completeness of followup.

Infection was identified as a common cause of death in the first 2 years after GCA diagnosis, and this may well be related to immunosuppression from higher doses of corticosteroids at that stage. This has implications with respect to infection prevention strategies in these patients, including vaccination and early treatment of infections.

We observed no cases of reactivated tuberculosis and there is no reported information about deaths or infection from tuberculosis in patients with GCA from high tuberculosis prevalence areas such as Eastern Europe or Asia.

Of additional interest was the 4 deaths observed from mesenteric infarction, which occurred 2-4 years after GCA diagnosis. Unfortunately, we do not have clinical information concerning corticosteroid use at time of death. A case series from Massachusetts recognized this complication in 12 patients with mesenteric ischemia and GCA; it was fatal in $50 \%{ }^{15}$.

We found that 6 patients had cerebrovascular accident listed as cause of death, of whom 3 had associated cardiac failure or atrial fibrillation, but there was no mention of stroke related to large artery occlusion on any of the death certificates. Although aortic aneurysm has been traditionally described as a complication in GCA, we did not find ruptured aneurysm mentioned as a cause of death on any of the death certificates in our group of patients.

One of the limitations of our study is that we do not have clinical information on the patients including information about GCA treatment, disease course, or other comorbidities such as preexisting cardiovascular disease and lung disease.

Our study demonstrated that patients with GCA have similar mortality rates to the general population. However, the risk of death from infection early in the disease may be increased, suggesting that vigilance for infection in this period is required.

\section{REFERENCES}

1. Gouet D, Marechaud R, Alcalay M. Survival in giant cell arteritis: a 14-year survey of 87 patients. J Rheumatol 1985;12:1209-10.

2. Gonzalez-Gay MA, Blanco R, Abraira V, García-Porrúa C, Ibáñez D, García-Pais MJ, et al. Giant cell arteritis in Lugo, Spain, is associated with low longterm mortality. J Rheumatol 1997;24:2171-6.

3. Gran JT, Myklebust G, Wilsgaard T, Jacobsen BK. Survival in polymyalgia rheumatica and temporal arteritis: a study of 398 cases and matched population controls. Rheumatology 2001;40:1238-42.

4. Garcia-Porrua C, Blanco FJ, Atanes A, Freire M, Graña J, Galdo F. Giant cell arteritis (GCA): survival analysis of 54 patients from Galicia, Spain [abstract]. Arthritis Rheum 1996;39 Suppl:S64.

5. Graham E, Holland A, Avery A, Russell RW. Prognosis in giant-cell arteritis. Br Med J (Clin Res Ed) 1981;282:269-71.

6. Hill CL, Cole A, Rischmueller M, Dodd T, Coleman M, Tucker G, et al. Risk of cancer in patients with biopsy-proven giant cell arteritis. Rheumatology 2010;49:756-9.

7. Nordborg E, Bengtsson BA. Death rates and causes of death in 284 consecutive patients with giant cell arteritis confirmed by biopsy. BMJ 1989;299:549-50.

8. Crow RW, Katz BJ, Warner JE, Alder SC, Zhang K, Schulman S, et al. Giant cell arteritis and mortality. J Gerontol A Biol Sci Med Sci 2009;64:365-9.

9. Bisgard C, Sloth H, Keiding N, Juel K. Excess mortality in giant cell arteritis. J Intern Med 1991;230:119-23.

10. Nesher G, Sonnenblick M, Friedlander Y. Analysis of steroid related complications and mortality in temporal arteritis: a 15 -year survey of 43 patients. J Rheumatol 1994;21:1283-6.

11. Uddhammar A, Eriksson AL, Nyström L, Stenling R, Rantapää-Dahlqvist S. Increased mortality due to cardiovascular disease in patients with giant cell arteritis in northern Sweden. J Rheumatol 2002;29:737-42.

12. Matteson EL, Gold KN, Bloch DA, Hunder GG. Long-term survival of patients with giant cell arteritis in the American College of Rheumatology giant cell arteritis classification criteria cohort. Am J Med 1996;100:193-6.

13. Salvarani C, Cantini F, Boiardi L, Hunder GG. Polymyalgia rheumatica and giant-cell arteritis. N Engl J Med 2002;347:261-71.

14. Huston KA, Hunder GG, Lie JT, Kennedy RH, Elveback LR. Temporal arteritis: a 25-year epidemiologic, clinical, and pathologic study. Ann Intern Med 1978;88:162-7.

15. Scola CJ, Li C, Upchurch KS. Mesenteric involvement in giant cell arteritis. An underrecognised complication? Analysis of a case series with clinicoanatomic correlation. Medicine 2008;87:45-51. 